\title{
Severe pulmonary embolism in COVID-19 patients: a call for increased awareness
}

\author{
Guillaume Hékimian ${ }^{1,2^{*}}$ (D) Guillaume Lebreton ${ }^{1,3}$, Nicolas Bréchot ${ }^{1,2}$, Charles-Edouard Luyt ${ }^{1,2}$, \\ Matthieu Schmidt ${ }^{1,2}$ and Alain Combes ${ }^{1,2}$
}

\section{Dear Editor,}

Coronavirus disease 2019 (COVID-19) is associated with severe systemic inflammation and important elevation of fibrinogen and D-dimers that has been associated with a poor prognosis $[1,2]$. This proinflammatory state might favor severe thromboembolic events and pulmonary embolism (PE).

We retrospectively reviewed characteristics of patients with confirmed SARS-CoV-2 infection and acute PE who were admitted to our tertiary ICU, which serves as an ECMO referral center for the Greater Paris. In accordance with the ethical standards of French legislation, only non-opposition of patient's surrogate for utilization of the deidentified data was obtained. The ICU database was registered with the national data protection authority (CNIL 1950673). No analysis for statistical significance was performed given the descriptive nature of the study.

From February 25, 2020, to April 6, 2020, 51 patients with confirmed SARS-CoV-2 infection were treated in our ICU, of whom 8 (16\%) had confirmed severe PE. Patients' main characteristics are described in Table 1. Four patients had PE while on VV-ECMO for severe ARDS. VAECMO was initiated in 3 other patients with refractory shock due to right ventricular failure, and one patient died of refractory cardiac arrest before ECMO could be installed. PE was suspected in 6 patients because of acute cor pulmonale at echocardiographic evaluation (online supplementary data). PE diagnosis was confirmed by CT angiography (online supplementary data) in 7 patients and

\footnotetext{
* Correspondence: guillaume.hekimian@aphp.fr

'Sorbonne Université, INSERM, UMRS_1166-ICAN, Institute of Cardiometabolism and Nutrition, F-75013 Paris, France

${ }^{2}$ Service de médecine intensive-réanimation, Institut de Cardiologie, APHP Hôpital Pitié-Salpêtrière, F-75013 Paris, France

Full list of author information is available at the end of the article
}

by autopsy in one patient. All except one had received anticoagulation before PE diagnosis. Five patients had a very high level of fibrinogen, and all had important increase in D-dimers. As of April 6, 2020, 3 patients had died of multiple organ failure and 5 are still on MV and ECMO in the ICU.

We describe a series of 8 critically ill patients with massive PE following COVID-19 infection. Four of these patients developed PE while on VV-ECMO for severe ARDS, a condition that was not reported in the $156 \mathrm{pa}$ tients included in the EOLIA trial [3] who received ECMO and in the $350 \mathrm{VV}$-ECMO patients of the LIFEGARDS international multicenter prospective cohort [4]. Interestingly, 7 of the 8 patients had received preventive anticoagulation that did not prevent PE. In 6 of the 8 patients, Doppler echocardiography showing acute right ventricle dilation prompted CT angiography that confirmed PE.

Massive PE in COVID-19 patients may be the consequence of sepsis-induced disseminated intravascular coagulation or to a specific procoagulant state caused by inflammation or virus-induced endothelial dysfunction [5]. Important elevation of D-dimers was indeed reported in these patients and was associated with subsequent ARDS and in-hospital mortality [5]. However, massive PE was not reported in previous series [1,2], although it may have been the unproven cause of death in some patients.

Our observation has potential major clinical implications. First, higher level of anticoagulation might be considered in patients with the most severe forms of the disease, those with high D-dimers and, contrarily to our previous recommendation, in patients supported by VV-ECMO [3]. Second, routine Doppler echocardiography should be performed daily to detect early signs of acute cor pulmonale in critically ill 


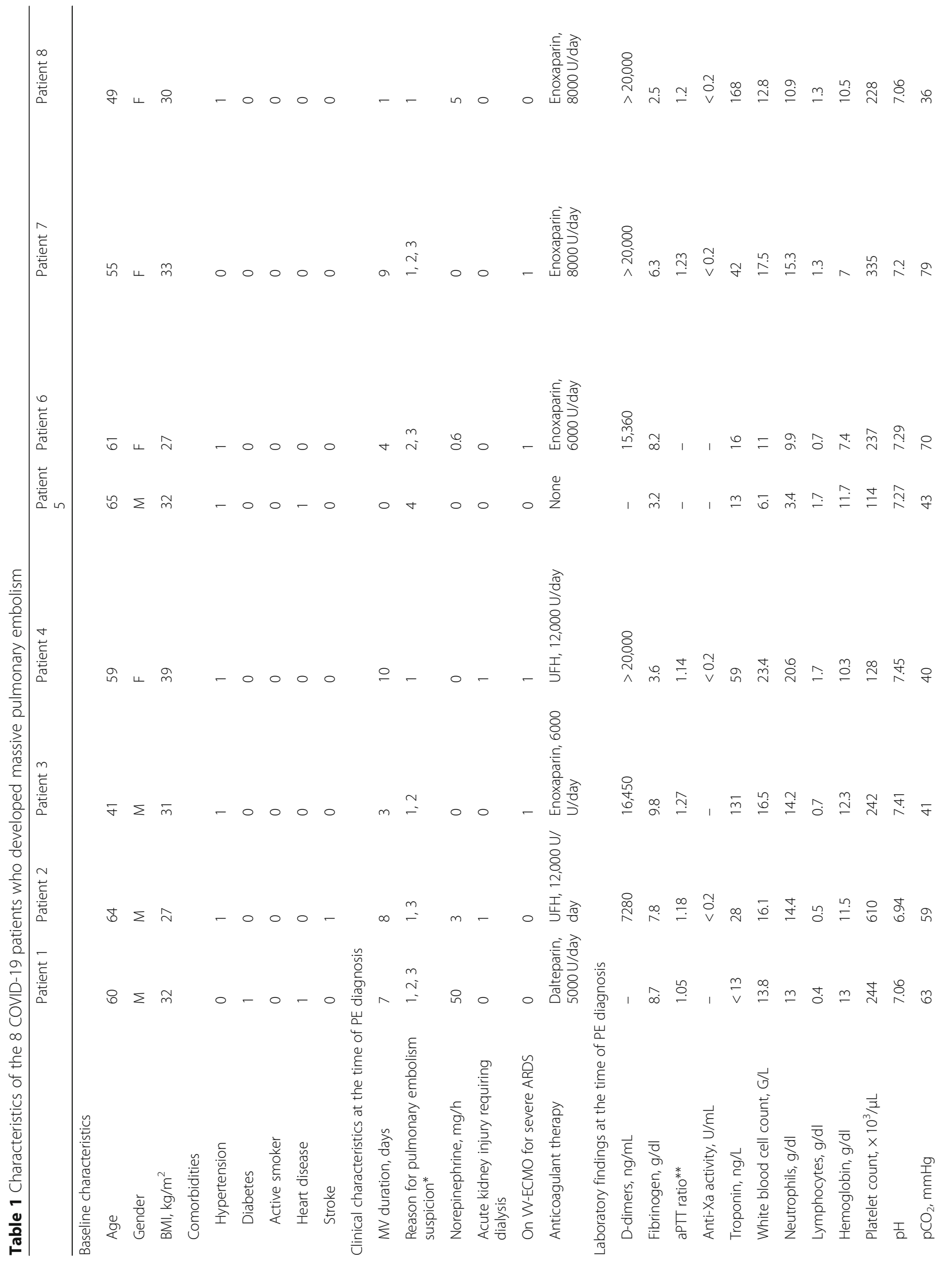




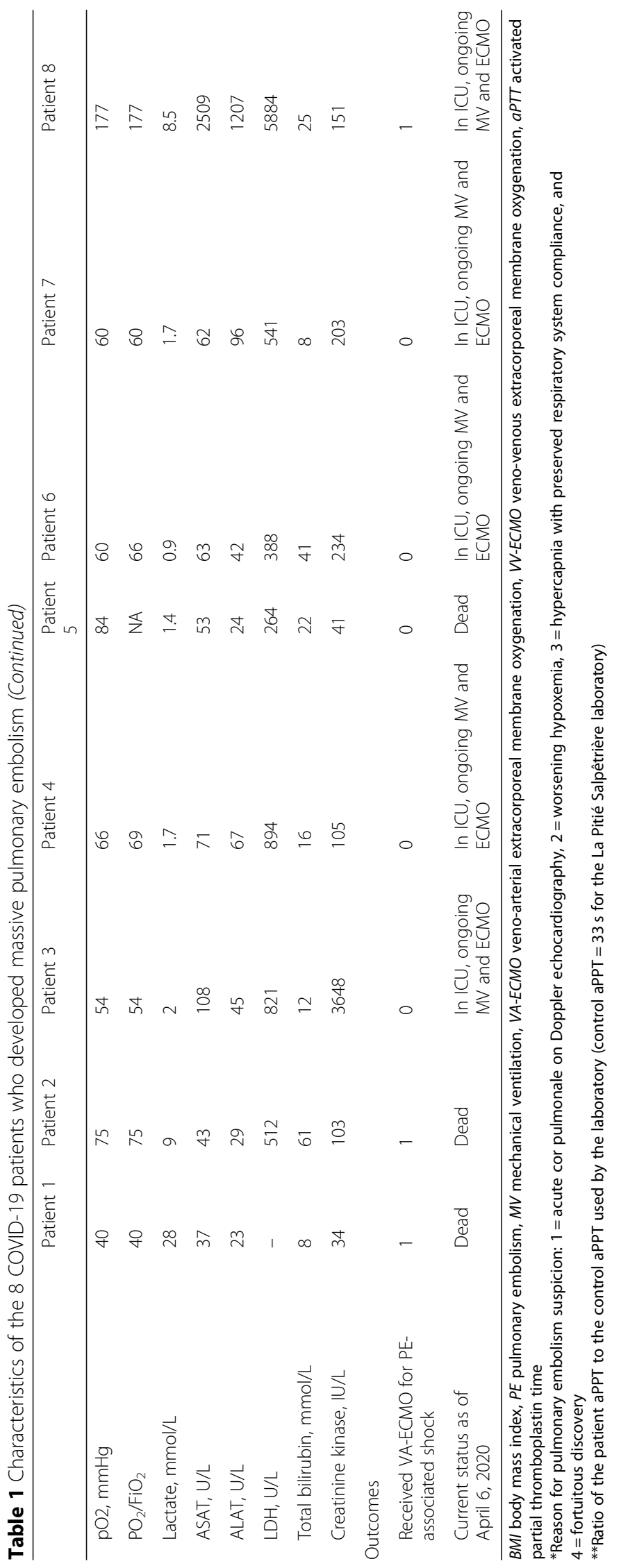


patients. Lastly, PE should also be suspected in COVID-19 patients with worsening hypoxemia or hypercapnia under mechanical ventilation.

This case series has several limitations. It is a small single-center case series of critically ill patients, we did not compare clinical and biological characteristics of patients with or without PE, and PE incidence could not be accurately estimated. However, we think that physicians should be warned about the occurrence of severe and potentially fatal PE in COVID-19 patients.

\section{Supplementary information}

Supplementary information accompanies this paper at https://doi.org/10. 1186/s13054-020-02931-5.

Additional file 1:

\section{Acknowledgments}

The authors thank Corinne Frère ${ }^{1} \mathrm{MD}, \mathrm{PhD}$, and Pascal Leprince ${ }^{3} \mathrm{MD}, \mathrm{PhD}$, for their help during the preparation of the manuscript.

\section{Authors' contributions}

$\mathrm{GH}$ and $\mathrm{AC}$ analyzed the results and drafted the manuscript. All authors participated in the data collection and final manuscript preparation and agreed with the latest manuscript.

\section{Funding}

None

\section{Availability of data and materials}

The datasets generated during the current study are available from the corresponding author on reasonable request.

\section{Ethics approval and consent to participate}

In accordance with French law and the ethical standards of our hospitals' institutional review board (Committee for the Protection of Human Subjects), informed consent was not obtained because this observational study did not modify existing diagnostic or therapeutic strategies. However, patients and/ or their relatives were informed about the anonymous data collection and were told that they could decline inclusion. This database is registered at the National Commission for Informatics and Liberties (CNIL registration no. 1950673).

\section{Consent for publication}

Not applicable

\section{Competing interests}

The authors declare that they have no competing interests.

\section{Author details}

${ }^{1}$ Sorbonne Université, INSERM, UMRS_1166-ICAN, Institute of Cardiometabolism and Nutrition, F-75013 Paris, France. ${ }^{2}$ Service de médecine intensive-réanimation, Institut de Cardiologie, APHP Hôpital Pitié-Salpêtrière, F-75013 Paris, France. ${ }^{3}$ Service de chirurgie thoracique et cardio-vasculaire, Institut de Cardiologie, APHP Hôpital Pitié-Salpêtrière, F-75013 Paris, France.

Received: 21 April 2020 Accepted: 30 April 2020

Published online: 02 June 2020

\section{References}

1. Wang D, Hu B, Hu C, Zhu F, Liu X, Zhang J, et al. Clinical characteristics of 138 hospitalized patients with 2019 novel coronavirus-infected pneumonia in Wuhan, China. JAMA. 323(11):1061-69.

2. Zhou F, Yu T, Du R, Fan G, Liu Y, Liu Z, et al. Clinical course and risk factors for mortality of adult inpatients with COVID-19 in Wuhan, China: retrospective cohort study. Lancet Lond Engl. 2020;395:1054-62.
3. Combes A, Hajage D, Capellier G, Demoule A, Lavoué S, Guervilly C, et al. Extracorporeal membrane oxygenation for severe acute respiratory distress syndrome. N Engl J Med. 2018;378:1965-75.

4. Schmidt M, Pham T, Arcadipane A, Agerstrand C, Ohshimo S, Pellegrino V, et al. Mechanical ventilation management during extracorporeal membrane oxygenation for acute respiratory distress syndrome. An international multicenter prospective cohort. Am J Respir Crit Care Med. 2019;200:1002-12.

5. Tang N, Li D, Wang X, Sun Z. Abnormal coagulation parameters are associated with poor prognosis in patients with novel coronavirus pneumonia. J Thromb Haemost JTH. 2020;18:844-7.

\section{Publisher's Note}

Springer Nature remains neutral with regard to jurisdictional claims in published maps and institutional affiliations.

\section{Ready to submit your research? Choose BMC and benefit from:}

- fast, convenient online submission

- thorough peer review by experienced researchers in your field

- rapid publication on acceptance

- support for research data, including large and complex data types

- gold Open Access which fosters wider collaboration and increased citations

- maximum visibility for your research: over $100 \mathrm{M}$ website views per year

At BMC, research is always in progress.

Learn more biomedcentral.com/submissions 